\title{
Analisis Akad Jual Beli Properti dengan Sistem Pembayaran Cash Bertahap
}

\author{
Yayat Rahmat Hidayat*, Selva Nur Fadhilah, Shakila Carisya Tsania \\ Fakultas Syariah Universitas Islam Bandung, Jl. Tamansari No.1 Bandung \\ *Correspondence email: yayatrahmathidayat@unisba.ac.id, selvanurfadhilah.snf@gmail.com, shakilacarisya @gmail.com
}

\begin{abstract}
Abstrak. Perumahan dengan model pembiayaan syariah saat ini mulai ditawarkan oleh developer properti syariah. Salah satunya adalah Nuansa Alam Setiabudi Clove yang menjual rumah tinggal dengan menggunakan akad istishna, tidak menggunakan pembiayaan melalui bank, tanpa sita, dan denda. Metode pembayaran yang digunakan adalah cash dan cash bertahap. Dalam pelaksanaannya terdapat kasus pembeli tidak melakukan pembayaran secara berturut-turut dengan rentang waktu yang disepakati pada saat berakad, yang mengakibatkan kerugian pada developer. Tujuan penelitian ini untuk menganalisis pelaksanaan dan solusi permasalahan dari jual beli properti syariah dengan metode pembayaran cash bertahap. Penelitian ini bersifat kualitatif menggunakan pendekatan studi kasus. Teknik analisis data menggunakan metode analisis deskriptif. Hasil penelitian menemukan bahwa konstruk akad yang dibuat oleh developer perlu diperbaiki dan ditambahkan yaitu pada Pasal 5 tentang Keterlambatan Pembayaran, Pasal 7 tentang Pembatalan Akad dan Ganti Rugi, dan Pasal 8 tentang Penyelesaian Perselisihan, untuk menghindari kerugian yang diakibatkan oleh sistem penjualan yang tanpa bank, tanpa sita, dan tanpa denda.
\end{abstract}

Kata kunci: akad istishna; kepemilikan rumah; cash bertahap

Abstract. Islamic property developers are currently starting to offer housing with the sharia financing model. One of them is Nuansa Alam Setiabudi Clove who sells his house using an istishna contract, does not use bank financing, without confiscation, and fines. The payment methods used are cash and cash in stages. In its implementation, there are cases where the buyer does not make payments in succession within the agreed time frame at the time of the contract, which results in losses to the developer. The purpose of this study is to analyze the implementation and solution to the problem of buying and selling Islamic properties with the cash payment method in stages. This research is a qualitative study using a case study approach. The data analysis technique used descriptive analysis method. The results of the study found that the contract construction made by the developer needs to be improved and added, namely in Article 5 concerning Late Payment, Article 7 concerning Contract Cancellation and Compensation, and Article 8 concerning Dispute Resolution, to avoid losses caused by a bankless sales system, without confiscation, and without penalty.

Keywords: istishna contract; house ownership; cash in stages

\section{PENDAHULUAN}

Islam merupakan agama yang sempurna, yang mengatur seluruh aspek kehidupan manusia, yang terdiri dari hubungan antara makhluk dan khalik (ibadah) maupun hubungan antara sesama makhluk (muamalah). Indonesia merupakan negara dengan populasi muslim terbesar di dunia dengan pertumbuhan penduduk mencapai $1,25 \%$ pertahun (sensus penduduk 2020). Hal ini menyebabkan permintaan rumah tinggal yang tinggi setiap tahunnya.

Allah telah menghalalkan jual beli dan mengharamkan riba (QS. Al-Baqarah [2]: 275), sehingga dalam mekanisme jual beli property harus terhindar dari riba. Saat ini banyak sekali program pemilikan rumah yang ditawarkan baik dengan akad syariah maupun konvensional. Beberapa developer bahkan ada yang menawarkan produk property tanpa berhubungan dengan bank, tanpa sita, dan tanpa denda. Salah satu akad yang ditawarkan yaitu akad ishtishna dengan pembayaran cash bertahap, yaitu pembeli dapat melunasi pembelian rumah dengan beberapa kali pembayaran. Jangka waktu yang ditetapkan pada sistem cash bertahap tidak sepanjang sistem KPR.
Salah satu developer syariah yang menawarkan penjualan property dengan sistem cash bertahap yaitu Nuansa Alam Setiabudi Clove yang berlokasi di Kota Bandung. Berdasarkan studi awal penulis, ternyata ditemukan beberapa masalah dalam metode pembayaran cash bertahap. Beberapa pembeli tidak melakukan pembayaran sesuai waktu yang telah disepakati pada awal atau terjadinya pembayaran macet secara berturutturut, sehingga menimbulkan kerugian pada pihak developer Nuansa Alam Setiabudi Clove. Berdasarkan masalah di atas maka penulis tetarik untuk meneliti model akad ishtishna yang digunakan dengan metode pembayaran cash bertahap.

Penelitian ini bertujuan untuk menganalisis model akad ishtishna dengan metode pembayaran cash bertahap dan memperbaiki kekurangan yang ada. Dengan demikian dapat menyempurnakan model akad ishtishna yang ada sehingga kerugian developer yang menerapkan metode pembayaran ini dapat diminimalisisr.

Penelitian tentang analisis akad ishtishna dengan metode pembayaran cash bertahap relative sedikit. Kebanyakan penelitian berpusat pada analisis status hukum Islamnya, seperti penelitian yang dilakukan oleh 
Deni Armayani dengan judul "Tinjauan Hukum Islam Tentang Sistem Pembayaran Cash Bertahap Pada Jual Beli Rumah. Penelitian ini menyatakan bahwa sistem jual beli rumah dengan pembayaran cash bertahap sesuai dengan hukum Islam karena menggunakan akad ishtishna dan telah memenuhi rukun dan syaratnya.(Armayani, 2019)

\section{Kerangka Pemikiran}

Jual beli property dengan prinsip syariah saat ini banyak ditawarkan oleh beberapa developer di Indonesia. Sistem pembayaran yang diterapkan yaitu menggunakan sistem cash bertahap. Sistem ini diterapkan untuk menghindari riba karena dalam praktiknya tidak berhubungan dengan bank sama sekali, bahkan pihak developer menekankan tidak adanya sita dan denda jika konsumen terlambat dalam melakukan pembayarannya. Pada satu sisi hal ini membuat daya Tarik, tetapi di sisi lain dapat menyebabkan krugian pada pihak developer apabila terjadi keterlambatan pembayaran secara terus menerus. Dengan demikian perlu dilakukan analisis terhadap draft akad yang dipakai untuk menminimalisir kerugian bagi pihak developer.

Akad yang digunakan adalah akad ishtishna. Istishna merupakan kontrak penjualan antara mustashni' (pembeli) dan shani' (suplier) dimana pihak suplier menerima pesanan dari pembeli menurut spesifikasi tertentu. Pihak suplier berusaha melalui orang lain untuk membeli atau membuat barang dan menyampaikannya kepada pemesan. Pembayaran dapat dilakukan di muka, cicilan atau ditangguhkan hingga waktu tertentu (Mansyur, 2007).

Dasar hukum akad istishna ada dalam Alquran surat Al-Baqarah ayat 282 yaitu:

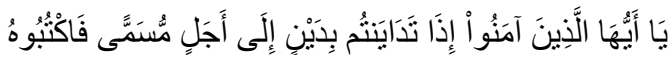

"Hai orang-orang yang beriman, apabila kamu bermuamalah tidak secara tunai untuk waktu yang tidak ditentukan, hendaklah kamu menuliskannya." (Departemen Agama Republik Indonesia, 2014)

Istishna merupakan akad yang tergolong dalam kategori akad jual beli sehingga sering juga disebut ba'i istishna. Allah telah menghalalkan jual beli dan mengharamkan riba sebagaimana firman-Nya dalam Alquran surat Al-Baqarah ayat 275, yaitu:

$$
\text { وَأَحَلَّ اللهُ الْبَيْعَ وَحَرَّمَ الرِّبَا }
$$

"Padahal Allah telah menghalalkan jual beli dan mengharamkan riba." (Departemen Agama Republik Indonesia, 2014).

\section{METODE \\ Objek Penelitian}

Objek penelitian adalah hal yang menjadi titik perhatian dari suatu penelitian. Titik perhatian tersebut berupa substansi atau materi yang akan diteliti atau dipecahkan (Sugiyono, 2009). Pada penelitian ini yang menjadi objek penelitian yaitu pelaksanaan jual beli properti syariah di Nuansa Alam Setiabudi Clove yang beralamat di Jalan Cirateun Peuntas No. 188, B2 (Setiabudi Dalam). Properti yang ditawarkan oleh Nuansa Alam Setiabudi Clove adalah rumah tinggal di Bandung dan pihak developer Nuansa Alam Setiabudi Clove sudah menjalankan bisnisnya dengan konsep syariah. Adapun penentuan informan dalam penelitian yang bersifat kualitatif ini yaitu dengan menggunakan cara purposive, yakni menentukan informan sesuai dengan kriteria yang relevan dengan masalah penelitian (Bungin, 2011).

\section{Pendekatan Penelitian}

Penelitian ini bersifat kualitatif, penelitian kualitatif yaitu penelitian dengan alasan bahwa dalam kegiatan ini, peneliti tidak menggunakan angka dalam mengumpulkan data dan memberikan penafsiran terhadap hasilnya, akan tetapi dalam hal tertentu peneliti boleh menggunakan angka (Bungin, 2011).

Penelitian ini menggunakan pendekatan studi kasus, yaitu suatu serangkaian kegiatan ilmiah yang dilakukan secara intensif, terinci dan mendalam tentang suatu program, peristiwa dan aktivitas, baik pada tingkan perorangan, sekelompok orang, lembaga, atau organisasi untuk memperoleh pengetahuan mendalam tentang peristiwa tersebut (Rahardjo, 2017).

\section{Jenis Data}

Prosedur pengumpulan data dalam penelitian ini dilakukan dengan menggunakan metode penelitian lapangan (field research) dan studi kepustakaan (library research), yaitu dengan meneliti langsung ke Nuansa Alam Setiabudi Clove Bandung yang terletak di Jalan Cirateun Peuntas Nomor 188, B2 (Setiabudi Dalam) serta melakukan studi kepustakaan untuk mendukung teori-teori dalam permasalahan yang ada (Arikunto, 1995).

\section{Sumber Data}

Penelitian ni menggunakan sumber data primer dan sekunder. Data primer adalah kata-kata dan tindakan orang-orang yang diamati (Moleong, 2009). Sumber data primer penelitian ini, penulis peroleh melalui kegiatan observasi dengan sekelompok orang (pihak developer) yang terlibat dalam pelaksanaan jual beli properti syariah di Nuansa Alam Setiabudi Clove.

Data sekunder adalah data yang tidak diberikan langsung kepada pengumpul data. Data sekunder diperoleh dari buku-buku yang membicarakan topik yang berhubungan langsung maupun tidak langsung dengan judul maupun pokok bahasan kajian, akan tetapi mempunyai relevansi dengan masalah yang dikaji (Sugiyono, 2009). Data yang diperoleh dari sumber data yang sudah jadi. Seperti dari skripsi, tesis, disertasi, 
jurnal dan juga buku-buku yang berkaitan dengan penelitian ini.

\section{Teknik Pengumpulan Data}

Penulis menggunakan beberapa teknik untuk mengumpulkan data, yaitu observasi, wawancara, dan dokumentasi. Observasi dalam penelitian ini dilakukan dengan cara peneliti terlibat dengan kegiatan sehari-hari orang yang sedang diamati atau yang digunakan sebagai sumber data penelitian. Pengamatan ini dilakukan secara langsung pada objek yang diteliti yaitu Nuansa Alam Setiabudi Clove.

Wawancara dilakukan pada pihak developer Nuansa Alam Setiabudi Clove yang terlibat dalam kegiatan jual beli. Adapun dokumen yang digunakan dalam penelitian ini adalah draft akad atau perjanjian jual beli antara developer Nuansa Alam Setiabudi Clove dengan pihak pembeli serta foto-foto terkait dengan Nuansa Alam Setiabudi Clove supaya penelitian lebih kredibel atau dapat dipercaya.

\section{Teknik Analisis Data}

Analisis data dalam penelitian ini menggunakan metode analisis deskriptif yaitu metode yang dapat diartikan sebagai prosedur pemecahan masalah yang diselidiki dengan menggambarkan atau melukiskan keadaan subjek atau objek penelitian (seseorang, lembaga, masyarakat, dan lain-lain) pada saat sekarang atau fakta-fakta yang tampak atau sebagaimana adanya (Soejono \& Abdurrahman, 1999).

\section{Kajian Teori \\ Jual Beli}

Lafadz ( آلَيَيُع dalam bahasa Arab menunjukkan makna jual dan beli. Secara bahasa (etimologi), mengandung tiga makna diantaranya tukar-menukar dengan harta, menukar sesuatu dengan sesuatu dan menyerahkan kompensasi dan mengambil sesuatu yang dijadikan sesuatu tersebut (Adam, 2018).

Adapun definisi jual beli (آلَبَيْعُ) secara istilah (terminologi) yaitu:

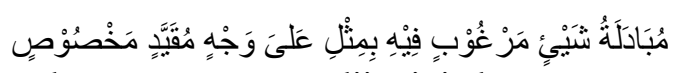

"Tukar menukar sesuatu yang diingini dengan yang sepadan melalui cara tertentu yang bermanfaat.".

Menurut mazhab Hanafi rukun jual beli adalah ijab dan qobul yang menunjukkan sikap tukar menukar atau saling member. Ataupun dengan kata lain, bahwa ijab qobul adalah perbuatan yang menunjukkan kesediaan kedua belah pihak untuk menyerahkan milik masing-masing kepada pihak lain dengan menggunakan perkataan dan perbuatan (Muslich, 2010). Sedangkan jumhur ulama menetapkan rukun jual beli ada 4 yaitu orang yang berakad (penjual dan pembeli), shighat (lafal ijab dan qabul), barang yang dibeli, dan nilai tukar pengganti barang (iwadh).
Dalam konteks hukum di Indonesia, menurut Kompilasi Hukum Ekonomi Syariah, unsur-unsur jual beli ada tiga yaitu penjual dan pembeli, kesepakatan atau ijab qabul, dan barang atau objek jual beli (Adam, 2018). Para ulama fikih sepakat menyatakan, bahwa orang yang melakukan akad jual beli itu harus memenuhi syarat berakal dan orang yang melakukan jual beli adalah orang yang berbeda. Syarat ijab dan qabul yaitu orang yang mengucapkannya telah baligh dan berakal, qabul harus sesuai dengan ijab, dan Ijab qabul dilakukan dalam satu majelis. Syarat terkait barang yang diperjualbelikan yaitu pihak penjual menyatakan kesanggupannya untuk menyediakan barang, barang tersebut dapat dimanfaatkan dan bermanfaat bagi manusia, milik seseorang, dan barang tersebut dapat diserahkan. Sedangkan syarat terkait nilai tukar yaitu harga yang disepakati kedua belah pihak harus jelas jumlahnya, boleh diserahkan pada waktu akad, sekalipun secara hukum, dan Apabila jual beli itu dilakukan denan saling mempertukarkan barang (al-muqayadhah), maka barang yang dijadikan nilai tukar bukan barang yang diharamkan syara', seperti babi dan khamr karena kedua jenis benda ini tidak bernilai dalam syara' (Adam, 2018).

\section{Istishna}

Secara bahasa (etimologi), istishna berasal dari kata ( صنع ) yang berarti membuat sesuatu dari bahan dasar. Ibn Abidin menjelaskan istishna adalah meminta dibuatkan suatu barang, yaitu meminta seorang pengrajin untuk membuatkan sebuah barang. Secara leksikal dikatakan, bahwa al-sana'ah berarti kerajinan tulisan seseorang pengrajin dan pekerjaannya adalah pengrajin. Lafadz sana'ah berarti pekerjaan seseorang pembuat barang atau kerajinan (Adam, 2017).

Sedangkan secara istilah (terminologi), istishna bisa diartikan akad jual beli pesanan antara pihak produsen atau penerima pesanan (shani') dengan pemesan (mustashni') untuk membuat suatu produk barang dengan spesifikasi tertentu (mashnu') dimana bahan baku dan biaya produksi menjadi tanggung jawab pihak produsen sedangkan sistem pembayarannya bisa dilakukan di muka, tengah atau akhir (Syarqawie, 2015).

Jual beli dengan akad istishna merupakan bentuk pemesanan pembuatan barang tertentu dengan kriteria dan persyaratan tertentu yang disepakati antara pemesan (pembeli) dan penjual (pembuat). Agar transaksi yang dilakukan sesuai dengan ketentuan syariah, maka adapun rukun dari akad istishna yang harus terpenuhi yaitu Pemesan (mushtashni'), Penjual (shani'), Barang atau objek akad (mashnu'), dan Ijab dan qabul (shigat) (Ikif \& Dkk, 2018).

Berkaitan dengan akad istishna, terdapat tiga syarat yang apabila salah satunya tidak terpenuhi maka akad istishna dianggap rusak atau batal, yaitu barang yang menjadi objek istishna harus jelas, baik jenis, kadar, macam, maupun sifatnya. Barang yang dipesan merupakan barang yang biasa digunakan untuk 
keperluan dan sudah umum digunakan, seperti pakaian, perabotan, rumah, furnitur, dan sebagainya, serta tidak diperbolehkan menetapkan dan memastikan waktu tertentu untuk menyerahkan barang pesanan (Adam, 2017).

Kontrak istishna bisa berakhir apabila tidak terpenuhinya kewajiban secara formal oleh kedua belah pihak, persetujuan kedua belah pihak untuk menghentikan kontrak, dan Pembatalan hukum kontrak ini jika muncul sebab ia masuk untuk mencegah dilaksanakannya kontrak atau penyelesaiannya, dan masing-masing pihak dapat membatalkannya (Syarqawie, 2015).

\section{Property Syariah}

Rumah sebagai hunian masyarakat merupakan kebutuhan primer, maka tidak heran ketika jual beli rumah menjadi bisnis yang menjanjikan Mekanisme jual beli haruslah memenuhi akad-akad yang menjadi dasar dalam jual beli (Candra, 2015). Jual beli pada dasarnnya mubah (boleh) yakni sepanjang tidak ada dalil yang transaksi jual beli tersebut dilarang (haram) dan rusak (fasid).

Jual beli properti syariah dapat dilaksanakan secara tunai dan kredit. Jual beli secara tunai (cash) adalah jual beli dengan sistem pembayaran terhadap barang yang dibeli secara tunai (langsung) tanpa tempo. Para ulama dalam hal ini tidak ada perbedaan pendapat tentang kebolehan jual beli tersebut. Jual beli kredit (bai' al-taqsit) ialah jual beli dengan sistem penyerahan barang di muka dan pelunasan harga ditempokan sebagian atau keseluruhan hingga batas waktu yang ditentukan. Pada umumnya, harga yang ditawarkan oleh pihak penjual lebih mahal dibanding harga cash (Sufah, 2014).

Akad yang digunakan dalam jual beli Properti Syariah yaitu murabahah dan istishna. Murabahah adalah pembiayaan saling menguntungkan yang dilakukan oleh shahib al-mal dengan pihak yang membutuhkan melalui transaksi jual beli dengan penjelasan bahwa harga pengadaan barang dan harga jual terdapat nilai lebih yang merupakan keuntungan atau laba bagi shahib al-mal dan pengembaliannya dilakukan secara tunai atau angsur. Akad istishna adalah jual beli barang atau jasa dalam bentuk pemesanan dengan kriteria dan persyaratan tertentu yang disepakati antara pihak pemesan dengan pihak penjual (Kompilasi Hukum Ekonomi Syariah, 2011).

\section{HASIL DAN PEMBAHASAN}

Jual beli properti syariah yang ada di Nuansa Alam Setiabudi Clove yaitu berupa jual beli rumah tinggal. Keuntungan yang ditawarkan kepada konsumen yaitu jual beli rumah tinggal ini terhindar dari denda, sita dan tanpa menggunakan pembiayaan melalui bank meskipun bank syariah. Sistem pembayaran jual beli properti syariah yang ada di Nuansa Alam Setiabudi Clove diantaranya:

1. Sistem Cash (Tunai)

Sistem cash (tunai) memberikan keuntungan berupa pemotongan harga sebesar Rp. 10.000.000,00 yang diberikan oleh pihak developer Nuansa Alam Setiabudi Clove, dengan ketentuan apabila pelunasan jual beli rumah tinggal di Nuansa Alam Setiabudi Clove dilakukan maksimal dalam 2 kali pembayaran dengan limit waktu 6 bulan.

2. Sistem Cash Bertahap

Sistem cash bertahap ini memberikan waktu lebih lama kepada pembeli untuk melunasi pembayaran rumah yang dibeli dibandingkan sistem cash (tunai) yang hanya memili tenggat waktu pelunasan selama 6 bulan. Konsumen hanya perlu membayar Booking fee sebesar Rp. 5.000.000,00 dan down payment (DP) sebesar 50\%. Sisanya dibayar dengan metode pembayaran cash bertahap dimana pihak pembeli harus melakukan pelunasan terhadap pihak developer Nuansa Alam Setiabudi Clove selambat-lambatnya maksimal 3 tahun.

Akad yang digunakan adalah akad istishna. Kontrak akad berisi dua bagian, bagian pertama berisi identitas penjual dan pembeli sedangkan bagian kedua berisi ketentuan akad yang disepakati penjual dan pembeli yang terdiri dari 10 pasal dan addendum.

Pasal pertama berisi ketentuan pokok tentang akad istishna menurut syara'. Pasal ini berisi pengertian akad istishna, ketentuan akad istishna, rukun dan syarat akad istishna, jangka waktu pembayaran, tata cara pembayaran, dan ketentuan hak khiyar, yaitu pilihan untuk melanjutkan atau membatalkan akad.

Pasal kedua berisi kesepakatan tentang spesifikasi rumah tinggal yang secara rinci tercantum dalam addendum. Pasal ini juga berisi ketentuan tentang usulan perubahan layout dan perubahan desain rumah yang dipesan pembeli beserta ketentuan pembayaran biaya tambahan sebagai akibat dari permintaan perubahan desain oleh pembeli.

Pasal ketiga berisi ketentuan harga dan kewajiban finansial yang ditanggung oleh penjual dan pembeli. Biaya yang ditanggung penjual meliputi SHM dan IMB. Biaya AJB, PBB, BBN, PPN, BPHTB dan biaya lain termasuk iuran-iuran setelah serah terima rumah ditanggung oleh pembeli.

Pasal keempat berisi ketentuan tentang cara pembayaran. Pasal ini meliputi kesepakatan jumlah booking fee, down payment, sisa down payment, sampai pelunasan pembayaran secara keseluruhan.

Pasal kelima berisi tentang kesepakatan keterlambatan pembayaran angsuran. Jika pembeli terlambat dalam membayar angsuran maka tidak akan dikenakan denda. Pembeli hanya diwajibkan untuk menyampaikan keterlambatan pembayarannya beserta alasannya. Jika penjual tidak menerima alas an yang 
disampaikan pembeli maka penjual berhak untuk menuntut kepada pembeli untuk segera membayarnya.

Pasal keenam berisi tentang mekanisme penyerahan rumah tinggal dan hak khiyar. Penyerahan rumah tinggal diatur berdasarkan kesepakatan pembeli dan penjual. Pada saat penyerahan dan jika spesifikasinya sesuai dengan yang tercantum di addendum maka pembeli tidak boleh menolaknya. Tetapi jika spesifikasinya tidak sesuai dengan yang tercantum di addendum maka pembeli memiliki hak khiyar, yaitu meminta penjual untuk memenuhi spesifikasi yang tercantum di addendum dengan memberikan tempo tambahan atau menolak barang tersebut dan meminta Kembali harga yang sudah dibayarkan.

Pasal ketujuh berisi kesepakatan mengenai pembatalan akad dan ganti rugi. Pembeli wajib membayar DP yang telah disepakati paling lambat 7 hari setelah kesepakatan ditanda tangani. Apabila pembeli tidak bisa memenuhi kewajibannya maka kesepakatan dianggap batal. Apabila pembeli membatalkan akad secara sepihak setelah pembayaran DP maka DP yang sudah dibayarkan dianggap hangus. Jika terjadi dharar yakni kerugian finansial pada salah satu pihak maka pihak yang dirugikan boleh menuntut ganti rugi.

Pasal kedelapan berisi tentang kesepakatan penyelesaian perselisihan. Jika terjadi perselisihan selama pelaksanaan akad jual beli, maka penjual dan pembeli menyepakati untuk menyelesaikan perselisihan itu secara kekeluargaan melalui musyawarah dan mufakat kepada ketentuan hukum syara'.

Pasal kesembilan berisi tentang kesepakatan masa pemeliharaan rumah tinggal. Masa pemeliharaan atas rumah tinggal yang diperjualbelikan adalah 60 hari kerja setelah serah terima bangunan. Objek pemeliharaan meliputi kerusakan-kerusakan yang muncul karena kualitas bangunan kurang baik, bukan karena unsur kesengajaan pemilik rumah dan juga bukan karena force major seperti kebakaran atau bencana alam. Kerusakankerusakan yang terjadi setelah masa pemeliharaan tersebut bukan menjadi tanggung jawab penjual walaupun masa angsuran masih berlangsung.

Pasal kespuluh berisi tentang kesepakatan lainlain. Pihak Penjual menjamin sepenuhnya bahwa tanah yang dijual adalah milik sah secara hukum syara' atau bebas dari sitaan, tidak tersangkut dalam suatu perkara atau sengketa, tidak sedang atau dijual kepada orang atau pihak lain. Akad ini dibuat oleh Pembeli dan Penjual dalam keadaan sadar tanpa tekanan pihak manapun. Dokumen ini dibuat dalam dua rangkap yang memiliki kekuatan hukum yang sama. Masing-masing salinan dipegang oleh Pembeli dan Penjual.

Kesepakatan terakhir dalam akad jual beli istishna ini adalah addendum. Addendum berisi tentang lokasi, luas tanah, dan luas bangunan rumah tinngal yang dipesan pembeli beserta spesifikasi bangunannya.

\section{Pembahasan}

Pada pelaksanaan jual beli properti syariah di Nuansa Alam Setiabudi Clove, terdapat keterlambatan pembayaran yang dilakukan oleh pihak Pembeli pada pihak Penjual sebesar 32\% dari total transaksi. Hal ini tentunya merugikan pihak Nuansa Alam Setiabudi Clove sebagai penjual. Proses transaksi pada jual beli rumah tinggal dengan menerapkan prinsip syariah tentunya harus diberikan apresiasi. Penjual menawarkan pembelian rumah tinggal tanpa berhubungan dengan bank untuk menjauhi riba, tanpa sita, dan tanpa denda jika terjadi keterlambatan pembayaran angsuran. Tetapi hal ini seringkali dimanfaatkan oleh pembeli yang kurang bertanggung jawab untuk menunda-nunda pembayaran angsurannya.

Berdasarkan analisis penulis terhadap draft akad, maka ditemukan tiga pasal yang harus diperbaiki, yaitu pasal 5, pasal 7, dan pasal 8.. Pasal-pasal tersebut antara lain:

\section{Pasal 5 Keterlambatan Pembayaran}

1. Keterlambatan pembayaran angsuran tidak dikenakan denda.

2. Dalam hal terjadi keterlambatan pembayaran (angsuran) oleh Pembeli dari tanggal jatuh tempo (tiap bulannya), Pembeli berkewajiban menyampaikannya kepada Penjual berikut alasan keterlambatan itu.

3. Dalam hal Penjual tidak bisa menerima keterlambatan berikut alasannya, dan tidak memberikan tempo tambahan kepada Pembeli, maka Penjual berhak menuntut Pembeli untuk segera membayarnya.

Pada pasal ini terlihat bahwa pihak developer Nuansa Alam Setiabudi Clove (Penjual) tidak memiliki ketegasan atas penuntutan pembayaran yang akan dilakukan jika pembeli terlambat dalam mebayar angsurannya. Pasal ini hanya menjelaskan apabila pihak Pembeli terlambat saat melakukan pembayaran pada setiap tanggal jatuh temponya maka pihak Penjual hanya menuntut pihak Pembeli untuk segera membayarnya saja. Di sini tidak terlihat bagaimana upaya yang dilakukan pihak Penjual agar pihak Pembeli melaksanakan kewajibannya secara tepat waktu dan jika dilanggar terdapat kesepakatan yang jelas serta kesepakatan tersebut tidak merugikan kedua belah pihak. Maka, dalam hal ini diperlukan beberapa point tambahan yang dapat mengikat kedua belah pihak diantaranya:

4. Dalam hal Penjual tetap tidak memberi tempo tambahan sementara Pembeli tetap tidak mampu membayarnya (sampai dengan 3 bulan berturut-turut) maka harus dilakukan kesepakatan berupa:

a. Pembuatan akad baru dengan pola pembayaran baru yang telah disepakati oleh pihak Penjual dan Pembeli.

b. Jika tidak terjadi kesepakatan pola pembayaran baru, maka pihak Pembeli diwajibkan mencari 
Pembeli Pengganti. Apabila harga jual lebih tinggi dari pada sisa pembayaran Pembeli, maka itu menjadi hak Pembeli. Setiap biaya yang timbul dari proses jual beli menjadi tanggung jawab Pembeli.

c. Jika Pembeli tidak dapat menghadirkan pengganti Pembeli maka pihak Penjual akan mencarikan Pembeli Pengganti. Pembeli hanya akan mendapatkan sejumlah uang sebagai haknya yang diserahkan oleh Penjual bila pihak Pembeli Pengganti telah membayarkan harga jual pada pihak Penjual seharga yang telah disetor Pihak Pembeli..

\section{Pasal 7 Pembatalan Akad dan Ganti Rugi}

1. Akad mengikat kedua belah pihak setelah pihak pertama memenuhi kewajiban penyerahan DP pada tanggal yang telah disepakati. Apabila selambatlambatnya 7 hari setelah akad ditandatangani di kedua belah pihak, pihak pertama tidak memenuhi kewajiban penyerahan DP maka akad istishna ini dinyatakan gugur.

2. Setelah akad ini disepakati dan pihak pertama telah memenuhi kewajiban penyerahan DP yang disepakati, maka kedua pihak baik Pembeli maupun Penjual tidak boleh membatalkan akad, baik barang belum dibuat atau sedang dibuat, kecuali atas persetujuan pihak lain.

3. Apabila akad jual beli ini dibatalkan atas keinginan sepihak dari pihak Pembeli maka seluruh dana yang telah dibayarkan kepada pihak Penjual dianggap hangus.

4. Jika terjadi dharar yakni kerugian finansial pada salah satu pihak maka pihak yang dirugikan boleh menuntut ganti rugi. Besarnya kerugian dan ganti rugi ditetapkan melalui kesepakatan diantara pembeli dan penjual.

Pada pasal ini developer Nuansa Alam Setiabudi Clove (Penjual) belum memberikan penjelasan mengenai tindak lanjut apabila pihak Penjual dan pihak Pembeli tidak mencapai kesepakatan dalam musyawarah dan mufakat, dengan demikian diperlukan penambahan point mengenai keberlanjutan dari hal tersebut yaitu:

5. Dalam hal tidak tercapai kesepakatan besarnya kerugian dan ganti rugi, maka penentuan kerugian dan ganti rugi maka penyelesaian perselisihan tersebut akan dibawa ke Badan Arbitrase Syariah Nasional atau Peradilan Agama.

\section{Pasal 8 Penyelesaian Perselisihan}

1. Dalam hal terjadi perselisihan selama pelaksanaan akad jual beli istishna ini hingga selesai seluruh kewajiban kedua pihak baik Pembeli dan Penjual, maka kedua pihak telah menyepakati untuk menyelesaikan perselisihan itu secara kekeluargaan melalui musyawarah dan mufakat dengan tetap mengacu kepada ketentuan hukum syara'.
Pada pasal ini pun sama halnya dengan pasal sebelumnya, yaitu developer Nuansa Alam Setiabudi Clove (Penjual) belum memberikan penjelasan mengenai tindak lanjut apabila pihak Penjual dan pihak Pembeli tidak ada kesepakatan sedangkan dalam pasal ini berisikan inti penyelesaian dari semua masalah yang ada, sehingga dalam hal ini diperlukan penambahan point agar lebih jelas yaitu:

2. Dalam hal tidak tercapai mufakat dan penyelesaian dalam musyawarah, kedua pihak menyepakati untuk membawa perselisihan ini ke Badan Arbitrase Syariah Nasional atau Peradilan Agama.

\section{SIMPULAN}

Pelaksanaan jual beli properti syariah di Nuansa Alam Setiabudi Clove sudah sesuai dengan ketentuan syara' yaitu dalam praktiknya telah menggunakan akad istishna. Hanya saja konstruk akad yang dibuat oleh Nuansa Alam Setiabudi Clove masih perlu ditambahkan beberapa point penting dalam beberapa pasal guna menghindari kerugian pada kedua belah pihak.

Pasal-pasal yang perlu diperbaiki yaitu Pasal 5 tentang Keterlambatan Pembayaran yaitu tindak lanjut pihak Penjual pada pihak Pembeli mengenai tidak adanya tempo tambahan sementara pihak Pembeli tetap tidak mampu membayar sisa tunggakannya, Pasal 7 tentang Pembatalan Akad dan Ganti Rugi yaitu tindak lanjut apabila tidak ditemui kesepakatan antara pihak Penjual dan pihak Pembeli mengenai penentuan kerugian dan ganti rugi, serta Pasal 8 tentang Penyelesaian Perselisihan yaitu tindak lanjut apabila pihak Penjual dan pihak Pembeli tidak menemukan mufakat dalam musyawarah dan penyelesaian perselisihan

\section{DAFTAR PUSTAKA}

Adam, P. (2017). Fikih Muamalah Maliyah. Bandung: PT. Refika Aditama.

Adam, P. (2018). Fikih Muamalah Adabiyah. Bandung: PT. Refika Aditama.

Arikunto, S. (1995). Dasar-Dasar Research. Bandung: Tarsito.

Armayani, D. (2019). Tinjauan Hukum Islam Tentang Sistem Pembayaran Cash Bertahap Pada Jual Beli Rumah. Skripsi, 103.

Bungin, B. (2011). Metode Penelitian Kualitatif (2nd ed.). Jakarta: Rajawali Press.

Candra, H. (2015). Cara Mudah Membeli Rumah KPR. Yogyakarta: Celta Media.

Departemen Agama Republik Indonesia. (2014). Alquran dan Terjemahnya. Bandung: Sygma Creative Media Corp.

Ikif, \& Dkk. (2018). Jual Beli Dalam Perspektif Ekonomi Islam. Yogyakarta: Gava Media.

Kompilasi Hukum Ekonomi Syariah. (2011).

Mansyur, H. (2007). Dimensi Perbankan dalam AlQuran (1st ed.). Jakarta: PT. Visi Citah Kreasi. 
Yayat Rahmat Hidayat, Selva Nur Fadhilah dan Shakila Carisya Tsania, Analisis Akad Jual Beli Properti dengan Sistem Pembayaran Cash Bertahap

Moleong, L. J. (2009). Metodologi Penelitian Kualitatif (26th ed.). Bandung: Remaja Rosdakarya.

Muslich, A. W. (2010). Fikih Mumalah. Jakaerta: Amzah.

Rahardjo, M. (2017). Studi Kasus dalam Penelitian Kualitatif: Konsep dan Prosedurnya. Malang: Universitas Islam Negeri Maulana Malik Ibrahim Malang.

Soejono, \& Abdurrahman. (1999). Metode Penelitian Suatu Pemikiran dan Penerapan. Jakarta: Rineka Cipta.

Sufah, T. K. F. A. (2014). Kamus Fikih (2nd ed.). Kediri: Lirboyo Press.

Sugiyono. (2009). Metode Penelitian KuantitatifKualitatif dan $R \& D$. Bandung: Alfabeta.

Syarqawie, F. (2015). Fikih Muamalah (1st ed.). Banjarmasin: Aswaja Pressindo. 